\title{
Gas Chromatographic-Mass Spectrometric Method for the Assessment of Oxidative Damage to Double-Stranded DNA by Quantification of Thymine Glycol Residues
}

\author{
S. P. Markey, C. J. Markey, T.-C. L. Wang, and J. B. Rodríguez \\ Section on Analytical Biochemistry, Laboratory of Clinical Science, National Institute of Mental Health, \\ Bethesda, Maryland, USA
}

\begin{abstract}
A technique for the measurement of thymine glycol at parts per million concentrations in double-stranded polymeric DNA is described. The procedure utilizes base to ring-open DNA-bound thymine glycol in the presence of monomeric $\left[{ }^{2} \mathrm{H}_{4}\right]$ thymine glycol as an internal standard, followed by reduction, solvolytic cleavage, and quantification of the characteristic methyl-2-methylglycerate released from polymeric DNA. Methyl-2-methylglycerate is derivatized to form the di-tert-butyldimethylsilyl [(TBDMS $)_{2}$ ] ether to enhance its gas chromatographic properties and electron ionization detection. This assay was tested by measuring thymine glycol levels in native, undamaged DNA (not purposefully oxidized). The measured quantities of thymine glycol are proportional to the amount of DNA analyzed. Components of DNA not containing oxidizable thymine do not contribute to the measured signal from methyl-2-methylglycerate-(TBDMS) ${ }_{2}$. These results indicate that there is approximately one thymine glycol per $10^{6}$ bases in undamaged DNA and that this value increases with storage of DNA in refrigerated aqueous solutions. (f Am Soc Mass Spectrom 1993, 4, $336-342$ )
\end{abstract}

$\mathrm{P}$ rogressive neurological diseases associated with aging humans, such as Alzheimer's or Parkinson's, may be the product of accumulated unrepaired DNA damage in nondividing neuronal cells [1, 2]. Damaged genes could be the result of oxidative stresses caused by infection, drugs, or environmental agents that may overwhelm the normal enzymatic capacity to repair DNA. Such unrepaired DNA damage may compromise the ability of a neuron to synthesize functional proteins for vital tasks. Damage to gene regions coding for repair enzymes would affect the ability of cells to survive and thus lead to progressive disorders. The subject of DNA repair and its role in disease has been an area of active investigation, as summarized previously [3, 4].

We have approached the postulates with regard to unrepaired DNA damage as a factor in human disease with the intent of developing methods for the direct measurement of damaged DNA bases in human tissue. Initial efforts in this project were focused on the measurement of thymine glycol, one of the oxidation

Address reprint requests to S. P. Markey, Building 10, Room 3D40, NTH, Bethesda, MD 20892. products of the base thymine [5-7]. Adelman et al. [8] demonstrated that formation of thymine glycol correlated to species metabolic rate and life span. The liquid chromatographic methods used in that study were not sufficiently sensitive to be applied to human DNA thymine glycol measurements. The value and significance of using thymine glycol as a marker of DNA oxidation have been established by a number of studies on damaged DN $\Lambda$ and the mechanism of its repair (Figure 1) [9-16].

There have been several published assays for quantifying thymine glycol in DNA using radiorhemical, immunoassay, chromatographic, and mass spectrometric procedures $[10,17-23]$. These have been successful in measuring the oxidative damage in solutions of DNA exposed to various chemical or radiochemical agents but have generally lacked the sensitivity required to be applied to clinical measurements, in vivo animal studies, or even cultured cell experiments, except when cells have been prelabeled with radioactive thymine [24-26]; however, one of the analytical procedures seemed particularly well suited for adaptation for gas chromatography-mass spectrometry (GC-MS) analysis. Schellenberg and Shaeffer [23] used a radiochemical procedure employing alkaline hydrolysis, fol- 


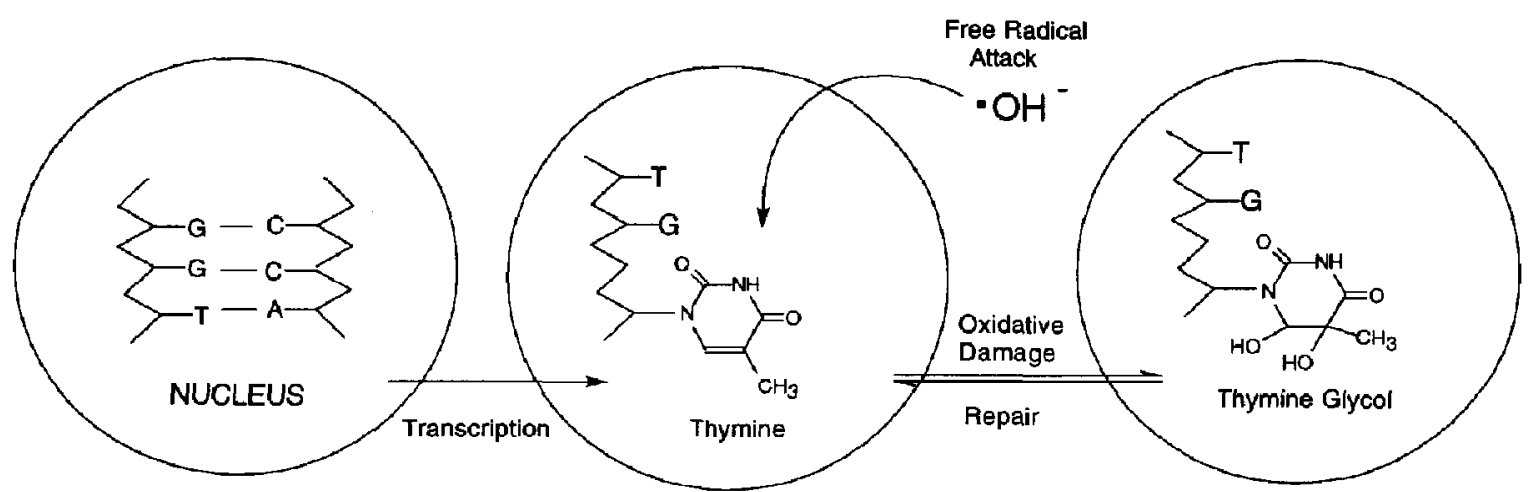

Figure 1. Oxidative damage to nuclear DNA occurs when DNA is single stranded within the cell nucleus. In nondividing neuronal cells, DNA is tightly folded, except during transcription. Thymine glycol is one of multiple products that are formed as the result of hydroxyl radical attack. Ordinarily, efficient repair enzymes excise and replace damaged bases in the DNA strand within a cell.

lowed by sodium $\left[{ }^{3} \mathrm{H}\right]$ borohydride reduction to cause thymine glycol in DNA to ring open. The resulting amide was cleaved by solvolysis with methanolic hydrochloric acid to release the methyl-2-methyl$\left[{ }^{3} \mathrm{H}\right]$ glycerate, which was quantified by scintillation counting. We modified this radiochemical procedure for stable isotope dilution GC-MS because it offered several substantive advantages for quantitative analysis. First, the selective cleavage of thymine glycol separates the bulk of the methanol insoluble DNA from methyl-2-methylglycerate. Second, this technique precludes the need for extensive separation and purification of nucleotides or nucleosides, significantly eliminating the chances of oxidative artifact formation. Third, by cleaving a four-carbon fragment from thymine glycol, the derivatization and gas-phase measurement is simplified considerably because methyl-2methylglycerate is a relatively stable, low molecular weight compound. (Figure 2),

This report summarizes a GC-MS (electron ionization) method for thymine glycol quantification and its application to preparations of DNA. In the course of this study, derivatization and analysis conditions were tested repedtedly with regard to artifact production, sensitivity enhancement, and consistency. The absence of polymeric reference materials precluded the option of preparing the known, standardized dilutions that are required for accurate isotope dilution assays and are characteristically used for GC-MS method development.

\section{Materials and Methods}

\section{Materials}

Tert-butyldimethylsilyl (TBDMS) chloride, thymine, imidazole, and decane were obtained from Aldrich Chemical Co. (Milwaukee, WI). Methanolic hydrochloric acid $(0.5 \mathrm{M})$ in sealed ampules was obtained from Supelco, Inc. (Bellefonte, PA). Sodium borodeuteride
$\left(\mathrm{NaB}\left[{ }^{2} \mathrm{H}_{4}\right]\right)$ was obtained from Merck and $\mathrm{Co}$. (Rahway, NJ). Sodium hydroxide (10 M NaOH) and acetonitrile (high-performance liquid chromatography grade) were obtained from Fisher Scientific (Fair Lawn, NJ). Hydrochloric acid and heptane were obtained

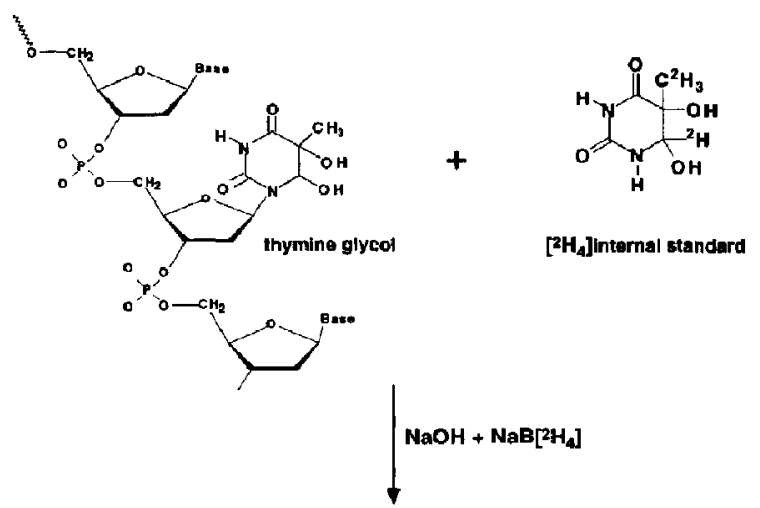

DNA

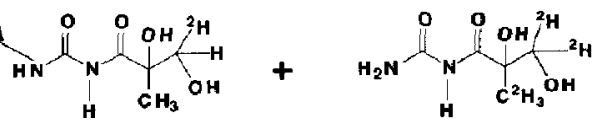

MeOHAHCI
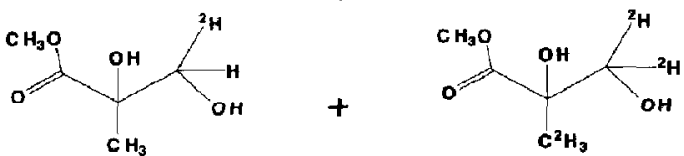

Figure 2. Formation of methyl-2-methylglycerate from thymine glycol in isolated polymeric DNA. When DNA is subjected to base hydrolysis, the thymine glycol ring opens, and borodeuteride reduction produces a labeled glycol. Methanolysis releases methyl-2-methylglycerate from the polymer strand. Soluble, monomeric $\left[{ }^{2} \mathrm{H}_{4}\right]$ thymine glycol is used as an internal standard to quantify the yield of these reactions. 
from Mallinckrodt (Paris, KY). Osmium tetroxide was obtained from Colonial Metals (Elkton, MD); sodium chlorate was obtained from J. T. Baker (Phillipsburg, NJ).

Salmon sperm DNA was obtained from Sigma Chemical Company (St. Louis, MO). Herring sperm DNA; the nucleotides deoxyadenosine 5 'triphosphate (dATP), deoxyinosine $5^{\prime}$-triphosphate (dITP), deoxythymidine 5'-triphosphate (dTTP), deoxyguanosine 5 -triphosphate (dGTP), and deoxycytosine $5^{\prime}$-triphosphate (dCTP); and the synthetic polymers poly (dA)poly(dT), poly[d(I-C)l, poly[d(A-T)], and poly(A) were obtained from Boehringer Mannheim (Indianapolis, IN).

Crystalline unlabeled $\left[{ }^{2} \mathrm{H}_{0}\right]$ thymine glycol $[2 \mathrm{H}(1 \mathrm{H}$, 3H)-pyrimidinedione-5,6-dihydroxy-5-methyl, Reg. 2943-56-8] was used as an external quantitative standard, and $\left[{ }^{2} \mathrm{H}_{4}\right]$ thymine glycol $\left(5-\left[{ }^{2} \mathrm{H}_{3}\right]\right.$ methyl-5,6-dihydroxy-6- $\left[{ }^{2} \mathrm{H}\right]$ pyrimidine-1,3-dione) was used as an internal standard. Small quantities of both were synthesized from thymine via permanganate oxidation following published procedures [7, 27-30]; however, to have sufficient crystalline thymine glycol for spectroscopic studies and gravimetric standards, an improved alternative synthetic preparation was investigated [31]. Thymine $(1 \mathrm{~g})$ was dissolved in hot water $(25 \mathrm{~mL})$ in a flask fitted with a reflux condenser and treated with osmium tetroxide $(0.030 \mathrm{~g})$ with stirring. The reaction was indintained under an argon atmosphere. After $10 \mathrm{~min}$, the reaction mixture became black, and sodium chlorate $(0.8 \mathrm{~g})$ was added [32]; the mixture was then maintained at $80{ }^{\circ} \mathrm{C}$ with vigorous stirring for 2 days. The reaction was monitored by thin-layer chromatography on silica [ethyl acetateacetonitrile (9:1) eluent; thymine retention approximately 0.4 ] and continued until all thymine was consumed. The reaction mixture was cooled to room temperature and extracted with carbon tetrachloride $(3 \times$ $30 \mathrm{~mL}$ ) to eliminate the osmium tetroxide [33]. The aqueous layer was concentrated under reduced pressure until a precipitate formed. The mixture of precipitate and aqueous layer was extracted with boiling acetonitrile $(50 \mathrm{~mL})$ for $60 \mathrm{~min}$ and filtered. The precipitate was extracted with boiling acetonitrile $(100 \mathrm{~mL})$ an additional five times. The combined acetonitrile extracts were evaporated, and the resulting amorphous solid was crystallized twice in water-ethanol to produce $840 \mathrm{mg}$ of pure thymine glycol (70\% yield): $\mathrm{mp}$ $223-228{ }^{\circ} \mathrm{C}$ (d). Lit $=214-216^{\circ} \mathrm{C}$ [27]. Anal. Calcd. for $\mathrm{C}_{5} \mathrm{H}_{8} \mathrm{~N}_{2} \mathrm{O}_{4} \cdot 1 / 3 \mathrm{H}_{2} \mathrm{O}, \mathrm{C} 36.15 \mathrm{H} 5.26 \mathrm{~N}$ 16.86. Found C $36.34 \mathrm{H} 5.14 \mathrm{~N} 16.93$. Infrared $\left(\mathrm{KBr}, \mathrm{cm}^{-1}\right) 3425$, $3365,3245,1735,1698,1671,1481,1228,1173,1089$, 1055, 985. ${ }^{1} \mathrm{H}$-nuclear magnetic resonance (NMR) [dimethylsulfoxide(DMSO)- $d_{6}$ )] $\delta=1.24$ [Methyl (Me) at C-6]; $4.36\left(\mathrm{dd}, J_{\mathrm{a}}=3.9 \mathrm{~Hz}, J_{\mathrm{b}}=2.1 \mathrm{~Hz}, 1 \mathrm{H}, \mathrm{H}-5\right) ; 5.33$ (s, $1 \mathrm{H}, \mathrm{HO}$ at $\mathrm{C}-6) ; 6.05(\mathrm{~d}, j=3.9 \mathrm{~Hz}, 1 \mathrm{H}, \mathrm{HO}$ at $\mathrm{C}-5)$; $8.16(\mathrm{~d}, J=2.1 \mathrm{~Hz}, 1 \mathrm{H}, \mathrm{H}-4) ; 10.05(\mathrm{~s}, 1 \mathrm{H}, \mathrm{H}-2){ }^{13} \mathrm{C}-$ NMR (DMSO- $d_{6}$ ) $\delta=23.49$ (Me at C-6); 71.17 (C-6); 78.68 (C-5); 152.46 (C-3); 174.41 (C-1). Chemical ioniza- tion mass spectrometry $(m / z, \%)=195\left(\left[\mathrm{M}+2 \mathrm{NH}_{3}\right.\right.$ $\left.+1]^{+}, 20\right) ; 178\left(\left[\mathrm{M}+\mathrm{NH}_{3}+1\right]^{+}, 100\right)$. Electron ionization mass spectrometry $(m / z, \%)=161\left([M+1]^{+}\right.$. 5); $142(10) ; 115(100) ; 99(35) ; 89(90)$. The infrared spectrum was measured with a BioRad (Cambridge, MA) model FTS 45 instrument. ${ }^{3} \mathrm{H}$ - and ${ }^{13} \mathrm{C}-\mathrm{NMR}$ experiments were recorded with a Varian (Sunnyvale, CA) Gemini 300 at 300 and $75 \mathrm{MHz}$, respectively. A Finnigan 4600 mass spectrometer (Finnigan-MAT, San Jose, CA) was used to record mass spectra via direct probe introduction.

\section{Sample Preparation}

Quantitative standards of $\left[{ }^{2} \mathrm{H}_{0}\right]$ thymine glycol (50 pg-100 ng in $10-100 \mu \mathrm{L} \mathrm{H}_{2} \mathrm{O}$ ) were aliquoted from accurately weighed and diluted thymine glycol for the standard curve. Quantitative DNA samples were prepared in water $(0.1-2 \mathrm{mg}$ in $100 \mu \mathrm{L})$. As internal standard, $10 \mu \mathrm{L}$ of $\left[{ }^{2} \mathrm{H}_{4}\right]$ thymine glycol $(1.6 \mathrm{ng} / \mu \mathrm{L})$ was included in every sample, excluding a procedural blank. The reactions were prepared in glass test tubes with Teflon-lined caps. A $0.2 \mathrm{M} \mathrm{NaOH}$ solution, prewashed three times with methylene chloride, was used to prepare $10 \mathrm{mM} \mathrm{NaB}\left[{ }^{2} \mathrm{H}_{4}\right]$ solution. The DNA samples were treated at $37^{\circ} \mathrm{C}$ for $1 \mathrm{~h}$ with $100 \mu \mathrm{L}$ of 10 $\mathrm{mM} \mathrm{NaB}\left[{ }^{2} \mathrm{H}_{4}\right] / 0.2 \mathrm{M} \mathrm{NaOH}$ to hydrolyze and reduce thymine glycol. The reaction was quenched with 100 $\mu \mathrm{L}$ of $6 \mathrm{M}$ hydrochloric acid; the sample tubes were vortexed and evaporated to dryness in a vacuum desiccator. Aliquots of methanolic hydrochloric acid (200 $\mu \mathrm{L}, 0.5 \mathrm{M})$ were added, and the samples were vortexed and then heated at $70^{\circ} \mathrm{C}$ for $30 \mathrm{~min}$. The samples were evaporated to dryness in a vacuum desiccator, and the residue was treated with $100 \mu \mathrm{L}$ of TBDMSimidazole reagent (prepared from $150 \mathrm{mg}$ TBDMSchloride and $170 \mathrm{mg}$ imidazole in $1 \mathrm{~mL}$ acetonitrile, then washed five times with equal volumes of heptane) at $70{ }^{\circ} \mathrm{C}$ for $30 \mathrm{~min}$ in a heating block. The methyl-2-methylglycerate-(TBDMS) ${ }_{2}$ derivative was extracted into $100 \mu \mathrm{L}$ of heptane/decane (90:10) after the addition of $100 \mu \mathrm{L}$ of water. The organic phase was remuved after freezing the tube with dry ice, transferred to tapered autosampler glass vial inserts, and concentrated in vacuo to a final volume of 20-25 $\mu \mathrm{L}$.

GC-MS analyses. Analyses were performed using either a Hewlett-Packard (Avondale, PA) 5890 GC/ 5970 mass selective detector or a Varian $3400 \mathrm{GC} /$ Finnigan-MA'T TSQ-70 spectrometer. A $30 \mathrm{~m}, 0.25 \mathrm{~mm}$ inside diameter, $0.15 \mu \mathrm{m}$ DB225 fused-silica column (J \& W Scientific, Folsom, CA) was programmed from $90^{\circ} \mathrm{C}(1 \mathrm{~min})$ to $180^{\circ} \mathrm{C}$ at $10^{\circ} \mathrm{C} / \mathrm{min}$, followed by a $40{ }^{\circ} \mathrm{C} / \mathrm{min}$ ramp to $240{ }^{\circ} \mathrm{C}$ (held $4 \mathrm{~min}$ ), with the injector port at $200^{\circ} \mathrm{C}$. The derivatized samples were dissolved in heptane/decane. Methyl-2-methylglycerate(TBDMS) ${ }_{2}$ eluted at approximately $160^{\circ} \mathrm{C}$. 


\section{Results and Discussion}

\section{Synthesis of Thymine Glycol}

Thymine glycol is not commercially available, and repeating the previously published procedures for permanganate oxidation of thymine $[27,28]$ resulted in highly variable yields of products that required extensive chromatographic separations and removal of copious quantities of salts prior to crystallization of small quantities of product. Consequently, we adapted procedures for the use of $\mathrm{OsO}_{4}$ instead of $\mathrm{KMnO}_{4}$ as an oxidizing agent $[31,33]$. The crude reaction product contained almost no side products, significantly reducing the difficulty in purification and crystallization. The yield of cis-thymine glycol from $\mathrm{OsO}_{4}$ oxidation of thymine was consistently $70 \%$. The analytical data $\left({ }^{1} \mathrm{H}\right.$ - and ${ }^{13} \mathrm{C}-\mathrm{NMR}$, infrared and mass spectra, melting point) were consistent with the assigned structure, and the combustion analysis indicated that the crystal lattice includes one water per three thymine glycol molecules.

\section{Characterization of Methyl-2-Methylglycerate Derivatives}

The GC-MS characterization of methyl-2-methylglycerate generated from thymine glycol necessitated synthesis of a reference material because of the unavailability of a commercial standard. Methacrylic acid oxidizes with $\mathrm{H}_{2} \mathrm{O}_{2}$ in formic acid, as previously reported [34], and the product 2-methylglycerate reacts with bis(trimethylsilyl)trifluoroacetamide. The resulting tris-trimethylsilylated acid was analyzed by GC-MS and identified by comparison of its mass spectrum with that previously published [34]. The 2-methylglycerate was then methylated with anhydrous methanolic hydrochloric acid, and the methyl ester was derivatized with a variety of reagents [bis(trimethylsilyl)trifluoroacetamide, trifluoroacetyl imidazole, TBDMS-imidazole] to permit selection of the derivative with the most desirable GC-MS characteristics for quantitative assay. Prominent structure-specific fragmention formation, stability to storage, and volatility were used to guide selection of suitable derivatives. For example, mass spectra of di-(trifluoroacetyl) derivative (molecular weight 326) exhibit prominent structure-specific fragment ions- $\left[\mathrm{M}^{+}-\mathrm{CO}_{2} \mathrm{CH}_{3}\right]$ $m / z$ 267, 25\%; [M+ $\left.{ }^{+}-\left(\mathrm{CO}_{2} \mathrm{CH}_{3}+\mathrm{CF}_{3} \mathrm{CO}_{2} \mathrm{H}\right)\right]_{.} m / z$ $154,30 \%)$ - with a base peak of $m / z 69\left(\mathrm{CF}_{3}^{+}\right)$. The high volatility of trifluoroacetyl derivatives of either the methyl or transesterified isobutyl ester of 2-methylglyceric acid preclude sample concentration by evaporation without significant losses, limiting the useful range of the assay. Methyl-2-methylglycerate(TBDMS) $_{2}$ permits lower limits of detection than other derivatives tested.

The electron ionization mass spectrum of methyl-2methylglycerate-(TBDMS) $)_{2}$ is shown in Figure $3 a$. As
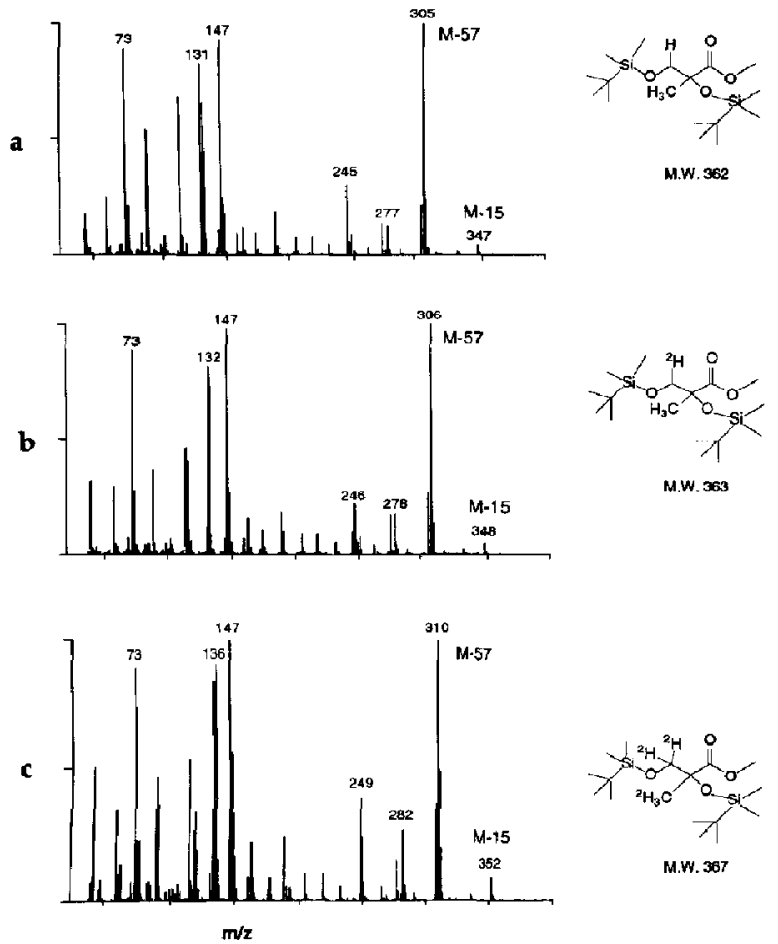

Figure 3. Electron ionization mass spectra of TBDMS derivatives of (a) synthetic methyl-2-methylglycerate; (b) $\left[{ }^{2} \mathrm{II}_{1}\right]$ methyl2-methylglycerate released from thymine glycol by hydrolysis and borodeuteride reduction; and (3) $\left[{ }^{2} \mathrm{H}_{5}\right]$ methyl-2-methylglycerate released from $\left[{ }^{2} \mathrm{H}_{4}\right]$ thymine glycol. Dominant ions result from the loss of a tertiary butyl group [M - 57] and reflect the degree of isotope incorporation, as do several other less intense but characteristic fragment ions at $[\mathrm{M}-15]$, [M-85], [M 117], and [M - 231].

is characteristic of TBDMS derivatives, fragmentation is dominated by an [M -57$]$ ion $(m / z$ 305), resulting from the loss of a tertiary butyl group. The derivatization chemistry was optimized after trying several variations of TBDMS reagents. Neither $N$-methyl- $N$ TBDMS-trifluoroacetamide nor distilled TBDMSimidazole, with or without added anhydrous hydrochloric acid for catalysis, produced a (TBDMS) derivative. Both reagents lack sufficient activity to react with the sterically hindered tertiary hydroxyl function at $70^{\circ} \mathrm{C}$, and at higher temperature, decomposition of the analyte occurs. In contrast reagent produced by formation of TBDMS-imidazole from crystalline imidazole and TBDMS-Cl in acetonitrile, although exhibiting abundant side products (silyl polymers) as background, yields a (TBDMS) 2 derivative under mild reaction conditions. This reagent is purified significantly by extraction with several aliquots of heptane, but total ion current recordings of procedural blanks. indicate the presence of a considerable variety of silyl by-products. Comparison of chromatographic separations using several common liquid phases showed that the lowest chemical background from reagents and 
excellent peak shape was obtained when a polarbonded liquid phase (50\% cyanopropylphenyl-50\% methyl silicone, DB225) was used.

Following optimization of derivatization and chromatography of methyl-2-methylglycerate-(TBDMS), we tested conditions for its generation from thymine glycol. The optimal conditions for hydrolysis and $\left[{ }^{3} \mathrm{H}\right]$ borohydride reduction of thymine glycol were described previously by Schellenberg and Shaeffer [23] and adapted for $\left[{ }^{2} \mathrm{H}\right]$ borohydride. The resulting product from crystalline thymine glycol contains a single deuterium atom, as shown in Figure $3 b$, exhibiting an [M - 57] fragment ion shifted from $m / z 305$ to 306 , compared with the product obtained when $\mathrm{NaBH}_{4}$ is used (Figure 3a). The product resulting from the hydrolysis and $\left[{ }^{2} \mathrm{H}\right]$ borohydride reduction of $\left[{ }^{2} \mathrm{H}_{4}\right]$ thymine glysol contains five deuterium atoms, with the $[\mathrm{M}-57]$ fragment ion shifted to $\mathrm{m} / \mathrm{z} 310$ (Figure 3c).

Combining the procedures for release of methyl-2methylglycerate with its derivatization and assay required several tests to prove that this assay was a valid quantitative measurement of thymine glycol in DNA. First, known and varying amounts of crystalline $\left[{ }^{2} \mathrm{H}_{0}\right]$ thymine glycol $(50 \mathrm{pg}-25 \mathrm{ng})$ were assayed in the presence of a constant amount of $\left[{ }^{2} \mathrm{H}_{4}\right]$ thymine glycol internal standard (approximately $16 \mathrm{ng} /$ tube). The resulting standard curves were consistently linear from 0.05 to $25 \mathrm{ng}$, indicating a lower limit of detectability of $100 \mathrm{pg} /$ tube. Second, weighed and varied amounts of two commercially available DNAs (herring and salmon sperm) were assayed for thymine glycol content. The results for selected ion monitoring of a procedural blank and a $0.5 \mathrm{mg}$ sample of native salmon sperm LNA are shown in Higure 4. 'Lhe signal representing unrepaired thymine glycol in these samples was measurable, distinct from the procedural blank, and was linear with increasing amounts of DNA over the range $0.1-2.0 \mathrm{mg} \mathrm{DNA} /$ tube $(y=0.025+0.036 x$; $r=0.938$ ), as indicated in Figure 5. Third, recycling and repetition of the hydrolysis/reduction treatment of DNA prior to methanolysis did not change the ratio for $\left.\left[{ }^{2} \mathrm{H}_{1}\right] /{ }^{2} \mathrm{H}_{5}\right]$ methyl-2-methylglycerate, indicating that the hydrolysis/reduction of thymine glycol was complete, whether in a DNA polymer or as the monomeric $\left[{ }^{2} \mathrm{H}_{4}\right]$ internal standard. Fourth, the selected ion current at $m / z 306$ used as a measure of thymine glycol was specific for the presence of polymeric or monomeric thymine glycol and was not influenced by other constituents of DNA. Commercially available nucleotides ( $250 \mu \mathrm{g}$ each of dATP, dTTP, dGTP, dCTP. dITP) and polymers $(0.5$ and $1.0 \mathrm{mg}$ of polyA, poly $(\mathrm{dA})$-poly $(\mathrm{dT})$, and poly[d(I-C)]\} were assayed to determine whether they contributed to the signal at $\mathrm{m} / \mathrm{z}$ 306. The results indicated that the $\left[{ }^{2} \mathrm{H}_{1}\right] /\left[{ }^{2} \mathrm{H}_{5}\right]$ ratio from $m / z 306 / 310$ was not influenced by the presence of deoxyglucose, phosphate, or the bases adenine, inosine, or cytosine. There was small but measurable contaminant interference at $\mathrm{m} / \mathrm{z}$

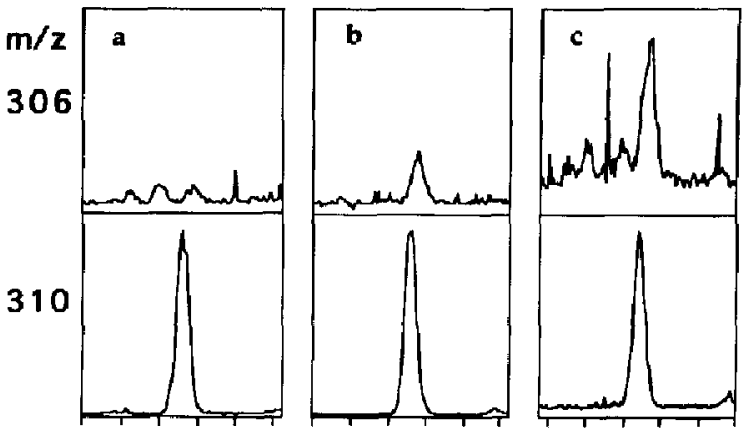

Figure 4. Selected ion chromatograms at $m / z 306$ (upper traces) used to measure $\left[{ }^{2} \mathrm{H}_{1}\right.$ ]methyl-2-methylglycerate, and at $m / z 310$ (lower traces) used to measure the internal standard $\left[{ }^{2} \mathrm{H}_{5}\right]$ methyl-2-methylglycerate. The signal from freshly dissolved salmon sperm DNA (b) corresponds to $0.5 \pm 0.1 \mathrm{ng}$ thymine glycol/mg DNA, in contrast to the procedural blank in (a) or the signal from the same DNA stored for 5 months in solution at $4{ }^{\circ} \mathrm{C}$ (c), corresponding to $1.86 \pm .06 \mathrm{ng}$ thymine glycol/mg DNA. Each chromatogram begins at $\sim 2.3 \mathrm{~min}$ and ends $\sim 13 \mathrm{~s}$ later $(2.45 \mathrm{~s} /$ scale division $)$.

306 from commercial guanosine and poly[d(I-C)], but the largest signals resulted from the thymine-containing materials [dTTP and poly(dA)-poly(dT)] that apparently partially oxidized on storage (Figure 6).

Although demonstration of the accuracy of this method for thymine glycol determination in DNA will require additional materials and assay comparisons, it is clear that this assay offers sufficient precision to detect increased levels of oxidation of thymine in DNA. For example, we have been able to detect the oxidation of DNA, which occurs on standing in refrigerated aqueous solutions. Salmon sperm DNA was weighed and dissolved in distilled water. The resulting viscous solution was stored at $4{ }^{\circ} \mathrm{C}$ in a plastic vial, and measurements indicated consistently increasing values of thymine glycol with respect to storage time when

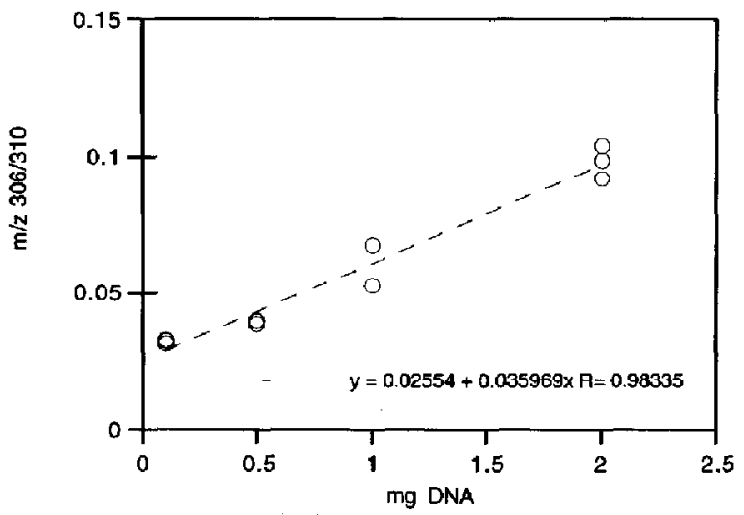

Figure 5. Replicate measurements of thymine glycol in different quantities of DNA over the range $0-2 \mathrm{mg}$ indicate the linearity and consistency of response for freshly dissolved salmon sperm DNA. 


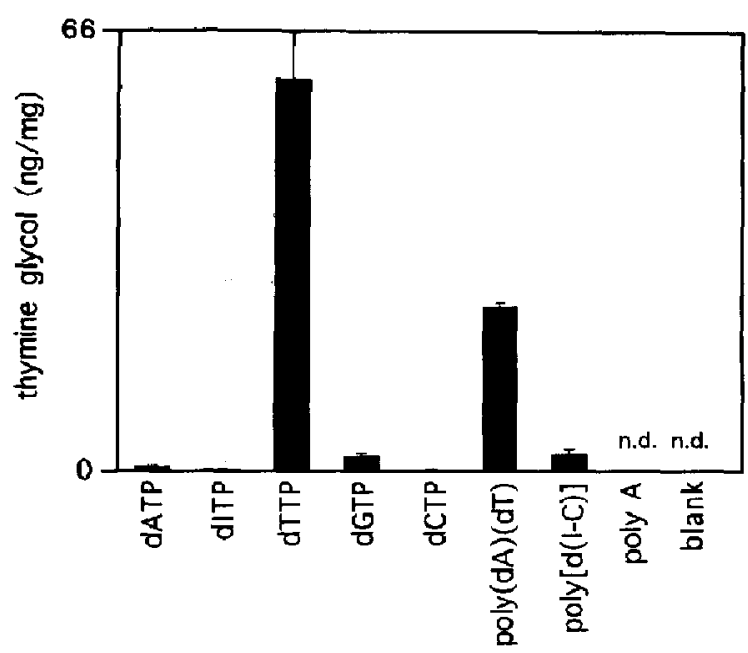

Figure 6. Measurement of thymine glycol in various commercially available substances to show that the use of $m / z 306 / 310$ is indicative of the presence of oxidized thymine and is not due to other constituents present in DNA (bases, deoxyribose, phosphate). Although none of these materials should contain thymine glycul, materials containing thymine invariably have measurable amounts of thymine glycol at ppm levels, presumably due to autooxidation.

assayed by GC-MS. Freshly prepared DNA solutions contained $0.5 \pm 0.1 \mathrm{ng}$ thymine glycol/mg DNA, whereas after 5-month storagc, that value incrcascd to $1.86 \pm 0.06$ (Figure 4). This observation has been confirmed by studies in progress (collaboration with $L$. Daniel and $Y$. Mao, National Cancer Institute) correlating thymine glycol formed when DNA is in contact with various forms of silica in solution with the extent of DNA strand breakage as detected by gel assays. Thus, the present assay exhibited sufficient precision to permit comparison of DNA isolated from cells or animals exposed to varying oxidative challenges, as judged by the fact that consistent results were measured for native, unclamaged DNA. The relatively large quantity of DNA required for measurement $0.5 \mathrm{mg}$ DNA/tube to quantify approximately $250 \mathrm{pg}$ in an assay that can detect $100 \mathrm{pg}$ /tube) imposes restraints on the application of this method to human clinical studies. If oxidative processes produce large increases in thymine glycol residues in the DNA being studied, then the amount of DNA being assayed can be reduced proportionally. Using the value of $0.5 \mathrm{ng}$ thymine glycol/mg DNA to define native, minimally damaged, double-stranded DNA, there is approximately one thymine glycol residue per $10^{6}$ bases, or four thymine glycol residues per $10^{6}$ thymine molecules (assuming that 25\% of the bases are thymine). This value is lower than that published for thymine glycol content in undamaged DNA determined by GC-MS measurement of thymine glycol released after formic acid hydrolysis ( $48-60 \mathrm{ng} / \mathrm{mg}$ DNA), but this may be due to differences in the DNAs as well as differences in the methodology $[35,36]$.
It would be desirable to reduce the amount of DNA required for each assay, and toward that objective we tested several alternative methods of mass spectrometric analysis. Using the same chemical derivatization method and GC separations, we compared standard curves, limits of detection, and the precision of results using electron ionization (EI), methane- or ammoniapositive chemical ionization (PCI), and tandem mass spectrometric analysis (MS/MS) [5]. The ion current signal from ammonia $\mathrm{PCI}\left[\mathrm{M}+\mathrm{NH}_{4}\right]^{+}$ions exceeded the $[\mathrm{M}-57]$ signal with EI for analysis of the same solutions of methyl-2-methylglycerate-(TBDMS) 2 but this did not translate into a lower limit of detectability because of higher chemical background. Sclected reaction monitoring MS/MS was investigated as a means to enhance assay selectivity by diminishing chemical background. No signal-to-noise improvements were realized compared with EI mass spectrometry for lowlevel standards using EI-MS/MS or PCI-MS/MS when a variety of ion transitions were monitored. This observation is probably consistent with the fact that the TBDMS derivatization procedure converts chemical interfering substances to compounds so closely related to the target analyte that favored collisionally induced transitions are equivalent in both analyte and chemical background. $\Lambda$ s a consequence, EI mass spec trometry is the preferred method of sample analysis.

Experiments are in progress to measure oxidation and repair of DNA in cultured cells using a variety of compounds that generate hydroxyl radicals when metabolized. Determination of the time course of repair of thymine glycol, as well as the differences between mitochondrial and genomic DNA, will be assayed in cultured cells to validate the assumption that thymine glycol in DNA is a valid measure of oxidative insult. Alternative derivatives to the methyl-2-methylglycerate-(TBDMS) ${ }_{2}$ are being investigated to use the sensitivity enhancement of negative chemical ionization mass spectrometry, with the expectation that assay sensitivity improvements would reduce directly the quantity of DNA required for assay, with the goal of 10-100 $\mu \mathrm{g}$ DNA/assay appropriate for clinical applications.

\section{Acknowledgments}

These studies were an outgrowth of work begun in collaboration with Dr. M. W. Duncan and Ms. C. McLellan, who synthesized the deuterated internal standard, and Dr. R. M. Cohen, who made helpful contributions to the initiation of this project. We thank the American Parkinson Disease Association, for grant support in 1989-1990, and the Alzhcimer's Disease and Related Disorders Association, for grant support for 1991-1992 (PRG-91104).

\section{References}

1. Marotta, C. A.; Majocha, R. E.; Coughlir, J. F.; Manz, H. J.; Davies, P.; Ventosa-Michelman, M.; Chou, W.-G.; Zain, S. B.; Sajdel-Sulkowska, E. M. In: Progress in Brain Research, vol. 
70; Swaab, D. F.; Fliers, E; Mirmiran, M.; Gool, W. A.; Van Haaren, F., Eds. Amsterdam: Elsevier, 1986, pp 303-320.

2. Robbins, J. H.; Otsuda, F.; Tarone, R. E.; Polinsky, R. J.; Brumback, R. A.; Nee, L. E. I. Neural. Neurosurg. Psychiatry 1985, 48, 916-923.

3. Halliwell, B.: Gutteridge, J. M. C. Free Radicals in Biology and Medicine, 2nd ed.; Oxford Univ. Press: New York 1989.

4. Friedberg, E. C. DNA Repair; Freeman: New York, 1984.

5. Markey, S. P.; Markey, C. J.; Wang, T.-C. L. Proceedings of the 40th ASMS Conference on Mass Spectrometry and Allied Topics; Washington, DC, 1992; pp 1131-1132.

6. Markey, S. P.; Markey, C. J. In Proceedings of the 39th ASMS Conference on Mass Spectrometry and Allied Topics; Nashville, TN, 1991; pp 969-970.

7. Duncan, M. W.; McLellan, C. A.; Markey, S. P.; Markey, C. I. Cohen, R. M. Proceedings of the $38 t h$ ASMS Conference on Mass Spectrometry and Allied Topics; Tucson, AZ, 1990; pp 718-719.

8. Adelman, R.; Saul, R. L.; Ames, B. N. Proc. Natl. Acad. Sci. USA 1988, 85, 2706-2708.

9. Basu, A. K.; Loechler, E. L.; Leadon, S. A.; Essigmann, J. M. Proc. Natl. Acad. Sci. USA 1989, 86, 7677-7681.

10. Cathcart, R.; Schwiers, E.; Saul, R. L.; Ames, B. N. Proc. Nat7. Acad. Sci. USA 1984, 81, 5633-5637.

11. Clark, J. M.; Pattabiraman, N.; Jarvis, W.; Beardsley, G. P. Biochemistry 1987, 26, 5404-5409.

12. Clark, J. M.; Beardsley, G. P. Biochemistry 1987, 26, 5398-5403.

13. Dizdaroglu, M.; Holwitt, E.; Hagan, M. P.; Blakely, W. F. Biochem. J. 1986, 235, 531-536.

14. Huselton, C. A.; Hill, H. Z. Environ. Mol. Mutagen 1990, 16 37-43.

15. Laspia, M. F.; Wallace, S. S. J. Mol. Biol. 1989, 207, 53-60.

16. Lee, K.; McCray, W. J.; Doetsch, P. W. Biochem. Biohys. Res. Commun. 1987, 149, 93-101.

17. Dizdaroglu, M. Anal. Biochem. 1985, 144, 593-603.

18. Dizdaroglu, M. In: Methods in Enzymology, vol. 193;
McCloskey, J. A., Ed.; San Diego: Academic, 1990; pp 842-857. 19. Weinfeld, M.; Soderlind, K.-J. M. Biachemistry 1991, 30, $1091-1097$

20. Hubbard, K.; Huang, H.; Laspia, M. F.; Ide, H.; Erlanger, B. F.: Wallace, S. S. Radiat. Res, 1989, 118, 257-268.

21. Sharma, M.; Box, H. C.; Kelman, D. J. Chem. Biol. Interact. 1990, 74, 107-117

22. West, G. I.; West, I. W.-L.; Ward, J. F. Radiat. Res. 1982, 90 , $595-608$.

23. Schellenberg, K. A.; Shaetter, J. Biochemistry 1986, 2b, $1479-1482$.

24. Lewis, J. G.; Adams, D. O. Cancer Res. 1985, 45, 1270-1275.

25. Lewis, J. C.; Hamilton, T.; Adams, D. O. Carcinogenesis 1986, $7,813-818$

26. Lewis, J. G.; Adams, D. O. Environ. Health Perspect. 1987, 76, $19-27$.

27. Frenkel, K.; Goldstein, M. S.; Duker, N. J.; Teebor, G. W. Biochemistry 1981, 20, 750-754.

28. Iida, S.; Hayatsu, H. Biochim. Biophys. Acta 1970, 213, 1-13.

29. Iida, S.; Hayatsu, H. Biochim. Biophys. Acta 1971, 240, 370-375.

30. Howgate, P.; Jones, A. S.; Tittensor, J. R. J. Chem. Soc. C 1968, 275.

31. Bergtold, D. S.; Howitt, E.; Simic, M. G.; Fresenius, J. Anal. Chem. 1990, 338, pp 383-385.

32. Trost, B. M.; Tinko, T. M.; Stanton, J. L. I. Chem. Soc. Chem. Commun. 1978, 436.

33. Woodward, R. B.; Bader, F. E.; Bickel, H.; Frey, A. J. Tetrahedron 1958, 2, 1.

34. Thompson, J. A.; Markey, S. P.; Tennessey, P. V. Clin. Chem, 1975, 21, 1892-1898.

35. Aruoma, O. I.; Halliwell, B.; Gajewski, E.; Dizdaroglu, M. Biochem. J. 1991, 273, 601-604.

36. Akman, S. A.; Doroshow, J. H.; Dizdaroglu, M. Arch. Biochem. Biophys. 1990, 282, 202-205. 